\title{
CHARAKTERISTIKA ANOMÁLNÍHO SKAPU V PUNKEVNÍCH JESKYNÍCH (MORAVSKÝ KRAS)
}

\author{
Characteristics of anomalous drip in Punkva caves (Moravian Karst) \\ Pavel Pracný', Jiří Faimon', Ludvík Kabelka² \\ 1 Ústav geologických věd PřF MU, Kotlářská 2, 61137 Brno; e-mail: pavelpracny@mail.muni.cz \\ ${ }^{2}$ GEOtest, a. s., Šmahova 1244/112, 62700 Brno
}

(24-23 Protivanov)

Key words: Punkva Caves, dripwaters, prior calcite precipitation, calcite saturation

\begin{abstract}
Cave speleothems grow from supersaturated dripwaters and store information about various karst processes along the water flow path. Anomalous non-saturated waters may occur if (1) rainfall water passes very rapidly through karst profile or if (2) two saturated waters of different compositions are mixed. The low mineralization close to saturation could be reached also as (3) result of calcite precipitating prior the water enters the cave. The hydrogeochemistry of four dripwaters in the Punkva Caves (Moravian Karst) was systematically studied for anomalous properties during one-year period. The drips are situated in a passage behind Přední Dóm Chamber (CP1 and CP2, 24 samples each), in Tunnel Corridor (TC1, 24 samples), and in Zadní Dóm Chamber (ZD1, 6 samples). The dripwaters CP1, CP2, and ZD1 show various flow regimes but very similar hydrogeochemical properties: electric conductivity $(E C=550-630 \mu \mathrm{S} / \mathrm{cm})$, saturation $\left(S_{\text {calcite }}=0.8-1.2\right)$, and $\mathrm{Mg} / \mathrm{Ca}$ ratio $\left(1000^{*}(\mathrm{Mg} / \mathrm{Ca})=15-20\right)$. In contrast, the dripwater TC1 shows stable drip rate and $E C=275-350 \mu \mathrm{S} / \mathrm{cm}, S I=-0.1$ to 0.3, and almost thrice as high $\mathrm{Mg} / \mathrm{Ca}$ ratios as other drips. High and stable discharge of the drip TC1, combined with low EC, SI close to zero, and high $\mathrm{Mg} / \mathrm{Ca}$ ratio indicate that a prior precipitation of calcite is responsible for the anomalous composition of the dripwater. The slightly negative SI values that were occasionally observed indicate that further minor processes probably participate on the water formation.
\end{abstract}

Úvod

Hydrogeochemické parametry skapových vod představují cenný zdroj informací o krasových procesech na cestě vody horninovým profilem. Tyto procesy mohou být ř́zeny celou řadou vlivů - zejména klimatickými. Informace o vývoji klimatu v minulosti mohou být vodítkem $\mathrm{k}$ pochopení současných klimatických změn. Proto jsou $\mathrm{v}$ současnosti předmětem zájmu skapové vody a speleotémy, které z nich vznikají.

Jeskynní skapy vznikají na místech, kde do jeskynních prostor volně vytéká prosakující voda. Tato voda se do horninového prostředí dostává infiltrací z povrchu a puklinami/průlinami protéká půdou a svrchní částí krasového profilu (epikras). Dochází k jejímu zadržování v epikrasu a postupnému pronikání níže do vadózní zóny. Od okamžiku vsaku voda reaguje s okolním prostředím. Dochází $\mathrm{k}$ rozpouštění plynného oxidu uhličitého př́itomného v pórech protékaných vodou. Výsledný roztok rozpouští karbonátové minerály př́tomné $\mathrm{v}$ hornině (vápenci), viz rovnice $1 . \mathrm{V}$ podmínkách tzv. otevřeného systému je $\mathrm{CO}_{2}(\mathrm{aq})$ spotřebovávaný rozpouštěním kalcitu doplňován $\mathrm{z}$ atmosféry, dokud není ustavena rovnováha atmosféra-voda-kalcit.

$\mathrm{CaCO}_{3}+\mathrm{H}_{2} \mathrm{O}+\mathrm{CO}_{2}=\mathrm{Ca}^{2+}+2 \mathrm{HCO}_{3}^{-}$

Výraz pro rovnovážnou konstantu je

$K_{T}=\frac{\left[\mathrm{HCO}_{3}^{-}\right]\left[\mathrm{Ca}^{2+}\right]}{P_{\mathrm{CO} 2}}$
Rovnováha mezi kalcitem a produkty rozpouštění je dána součinem rozpustnosti

$K_{C}=\left[\mathrm{CO}_{3}^{2-}\right]\left[\mathrm{Ca}^{2+}\right]$

Jeho hodnota se mění s teplotou - pro $15^{\circ} \mathrm{C}$ je $\mathrm{pK}_{\mathrm{c}}=8,38$ a pro $5{ }^{\circ} \mathrm{C}$ je $\mathrm{pK}=8,36$ (Jacobson - Langmuir 1974). Zpětná rovnice popisuje opačný proces - srážení kalcitu. Stupeň nasycení roztoku minerálem se vyjadřuje indexem nasycení, SI:

$S I=\log \frac{Q}{K}$

kde Q je reakční kvocient a $\mathrm{K}$ je rovnovážná konstanta. $\mathrm{V}$ rovnováze je $\mathrm{K}=\mathrm{Q}$ a SI se pak rovná nule. Je-li index nasycení kladné číslo, je roztok přesycený a budou se z něj vylučovat „přebytečné“ složky a krystalizovat pevná fáze. Pokud je záporný, je roztok nenasycený a bude naopak minerál rozpouštět.

Dynamika interakce kalcit - voda je poměrně rychlá - odhadované časy zadržení vody v krasovém profilu jsou dostatečné $\mathrm{k}$ dosažení rovnováhy. V nižší části vadózní zóny je předpokládán systém uzavřený vzhledem k plynnému $\mathrm{CO}_{2}$ : voda zde proudí póry a puklinami bez kontaktu s plynným $\mathrm{CO}_{2}$. Z těch nakonec ústí do jeskynních prostor, kde panují odlišné podmínky - zejména nižší $\mathrm{P}_{\mathrm{CO} 2}$, řízený ventilací jeskyně. Ve snaze vyrovnat parciální tlaky skapová voda odplyňuje přebytečný oxid uhličitý, tím zvyšuje $\mathrm{pH}$ a aktivitu $\mathrm{CO}_{3}^{2-}$ iontu a stává se přesycenou kalcitem. Ten se začne srážet a vytváří jeskynní speleotémy (sintry, stalaktity, záclony apod.). Z jeskynních prostor je voda odváděna dále do freatické zóny a mimo krasovou oblast. 
Ne vždy ale pozorujeme $\mathrm{v}$ jeskyních přesycenou skapovou vodu - předchozí hydrogeochemický výzkum zaměřený na korozi speleotém (Faimon et al. 2004), odhalil v Tunelové chodbě v Punkevních jeskyních anomální skap nenasycený ke kalcitu (SI $=-0.8$ až -0.3$)$. Jednou z prríčin může být to, že (1) část srážkové vody vadózní zónou proudí velmi rychle podél přednostních cest (např šachtový tok ze závrtů). Taková voda není při průchodu profilem $\mathrm{v}$ kontaktu $s$ horninou dostatečně dlouho pro ustavení rovnováhy a při vyústění do jeskyně je nenasycená kalcitem $(\mathrm{SI}<0)$. Vzhledem $\mathrm{k}$ velkému průtoku by pro takovou vodu byla typická sezónnost a velká variabilita ve vydatnosti (Smart - Friederich 1982).

Další příčinou může být (2) mixování vod s rozdílným složením (obsahy rozpuštěných karbonátů a vápníku). Každá $\mathrm{z}$ výchozích vod může být přitom v rovnováze s kalcitem - jejich rozdílná mineralizace je dána odlišnými podmínkami formování, zejména odlišným $\mathrm{P}_{\mathrm{CO} 2(\mathrm{~g})}$. Takové mísení lze očekávat v místech křížení puklin nebo $\mathrm{v}$ šachtách a komínech, kde voda stéká ve formě filmu na stěnách. Výsledný mix vod původně $\mathrm{v}$ rovnováze $\mathrm{s}$ kalcitem bude vždy nenasycený a bude směřovat $\mathrm{k}$ nové rovnováze $\mathrm{s} \mathrm{CO}_{2(\mathrm{~g})}$ a karbonátem. V prrípadě rychlého průniku nadložím vstupuje tato voda do jeskynního prostředí jako nenasycená. Vzhledem ke složitosti vodních cest $\mathrm{v}$ krasovém profilu je možné, že k mixování původně oddělených vod dochází také např̀ při nadměrných srážkách a přetocích sousedících kolektorů v epikrasu. Hydrologie skapů s mixovanými vodami tak může být velmi proměnlivá (Tooth - Fairchild 2003).

Posledním mechanismem je (3) předchozí srážení kalcitu před vstupem do jeskyně (prior calcite precipitation - PCP). Voda v tomto prŕpadě protéká volnými prostory, jejichž atmosféra má nižší parciální tlak $\mathrm{CO}_{2}$ než odpovídá rozpuštěným karbonátovým složkám, $\mathrm{P}_{\mathrm{CO} 2(w)}$. Voda reaguje odplyněním, stává se přesycenou a vylučuje kalcit. $\mathrm{V}$ malých prostorách by se $\mathrm{P}_{\mathrm{CO} 2} \mathrm{~V}$ atmosfére rychle vyrovnal $s \mathrm{P}_{\mathrm{CO} 2(\mathrm{w})}$. PCP lze proto očekávat ve větších, dobře ventilovaných prostorách. Svou roli hraje také kinetika odplyňování vody - čím větší je plocha tělesa vody a menší celkový objem, tím rychleji se vyrovná $\mathrm{P}_{\mathrm{CO} 2(\mathrm{~g})}$ a $\mathrm{P}_{\mathrm{CO} 2(\mathrm{w})}$. Z hlediska vydatnosti není důvod předpokládat, že se voda předběžně srážející kalcit bude lišit od běžných průsakových skapových vod, dá se ale očekávat intenzivnější PCP v obdobích s nízkými průtoky (Fairchild et al. 2000).

Při rozpouštění karbonátových hornin voda zvyšuje svou mineralizaci. $Z$ kationů se na mineralizaci podílí zejména $\mathrm{Ca}^{2+} \mathrm{z}$ kalcitu, méně $\mathrm{Mg}^{2+} \mathrm{z}$ dolomitu a hořečnatého kalcitu. Poměr mezi obsahem vápníku k hořčíku je určován několika procesy (Fairchild et al. 2000; Fairchild - Treble 2009). Prvním z nich je (1) předběžné srážení kalcitu - tento proces vede $\mathrm{k}$ poklesu koncentrace vápníku a tím $\mathrm{k}$ nárůstu poměru $\mathrm{Mg} / \mathrm{Ca}$. Vzhledem k nestechiometrickému nepublikovaná práce). rozpouštění vápence je důležitým faktorem (2) čas zadržení vody v krasovém profilu. Je také možné, že dochází k (3) selektivnímu uvolňování Mg z kalcitu (Morse - Arvidson 2002). V neposlední řadě může variace v koncentracích stopových prvků způsobit (4) mixování a ředění vod.

\section{Studovaná lokalita a metodika}

Skapové vody byly vzorkovány v Punkevních jeskyních, což jsou veřejnosti zpřístupněné jeskyně v severní části Moravského krasu asi $12 \mathrm{~km}$ v. od Blanska. Jeskynní systém byl zformován řekou Punkvou. Je vyvinut v lažáneckých a vilémovických vápencích macošského souvrství (Balák 1984).

Prezentovaná data představují dva skapy v chodbě za Předním dómem (skapy CP1 a CP2), skap v Tunelové chodbě (skap TC1) a skap v Zadním dómu (ZD1),

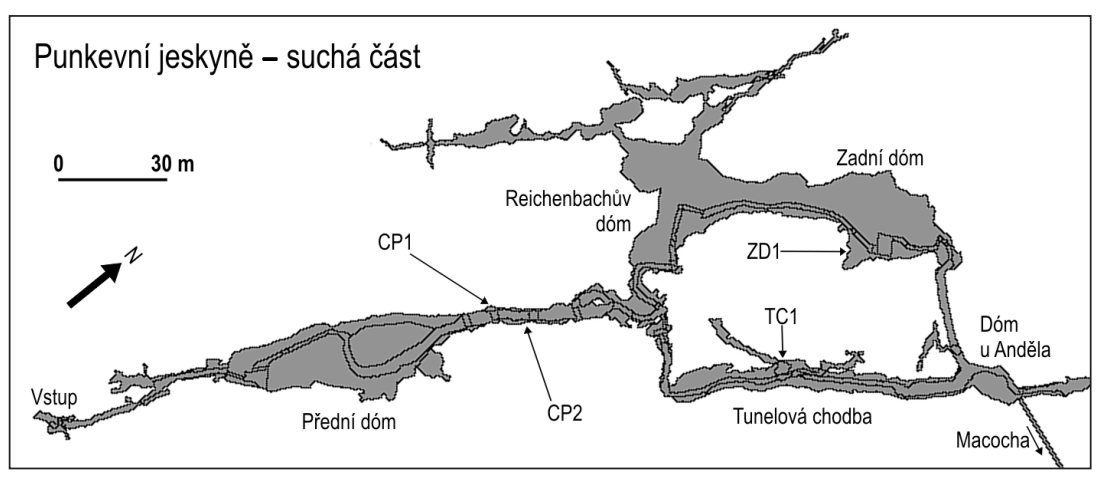

Obr. 1: Mapa části Punkevních jeskyní s vyznačenou polohou studovaných skapů (Balák,

Fig. 1: Map of Punkva Caves with marked location of studied drips (Balák, not published). viz obr. 1. Zdrojem skapů za Předním dómem jsou drobná brčka po levé straně chodby směrem od vchodu. Voda skapu TC1 v Tunelové chodbě kape ze záclonky asi $30 \mathrm{~cm}$ široké, vyvinuté na hraně ústí komína. Skap ZD1 kape ze stropu Zadního dómu na speleotému „Váza“ z výšky cca $20 \mathrm{~m}$. Vzorky byly odebírány dvakrát měsíčně v období od února 2012 do února 2013. Prezentovaná data pro skapy CP1 a CP2 a TC1 a hydrologie skapu ZD1 pochází z 24 měření. Z důvodu nízké vydatnosti, která neumožňovala vzorkování, bylo ze skapu ZD1 k dispozici pouze 6 vzorků.

Přímo na místě byly u vzorků měřeny $\mathrm{pH}$, vodivost a stanovena alkalita (acidimetrickou titrací) a koncentrace vápníku (komplexometrickou mikrotitrací). Vydatnost (rychlost) skapu byla určována počítáním kapek během standardního časového intervalu 1 min. Kompletní chemické analýzy byly následně provedeny v laboratoři za použití ICP-MS. Saturační indexy byly vypočítány modelovacím softwarem PHREEQC (Appelo - Parkhurst 1999).

\section{Výsledky a analýza dat}

Hydrogeochemické parametry skapových vod z Punkevních jeskyní jsou na obrázku 2a. Skapy CP2 a TC1 vykazují relativně stálou vydatnost (variační koeficient $<50 \%$ ), zatímco vydatnost skapů $\mathrm{CP} 1$ a $\mathrm{ZD1}$ je proměnlivější (variační koeficient $>50 \%$ ). V průběhu roku vykazovala vydatnost všech skapů slabě klesající trend. Maximální 


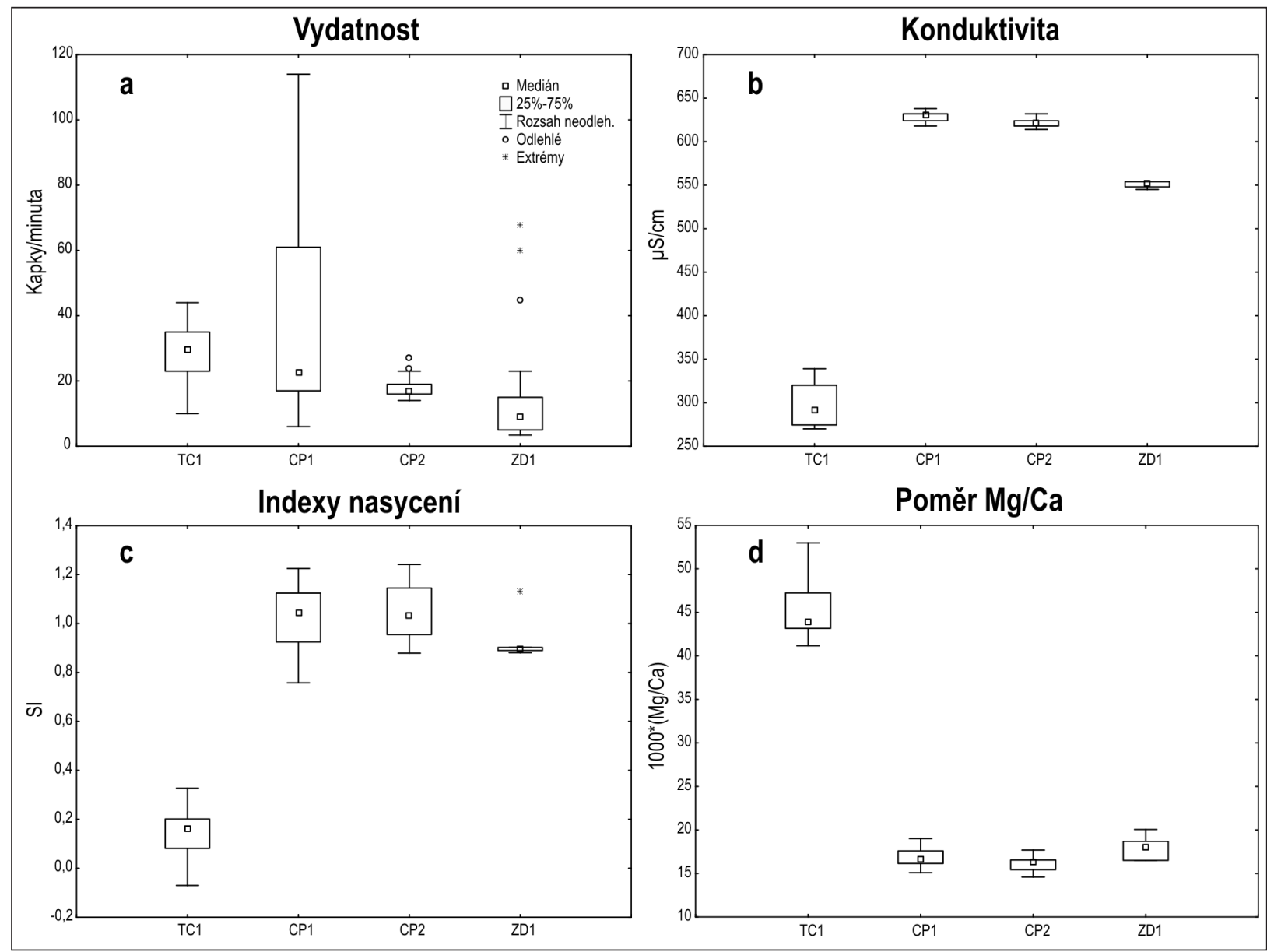

Obr. 2: Hydrogeochemické vlastnosti skapových vod v Punkevních jeskyních v období od února 2012 do února 2013 (TC1, CP1 a CP2 znázorňuje 24 měření; ZD1 znázorňuje 6 měření).

Fig. 2: Hydrogeochemical parameters of dripwaters from Punkva Caves in the period from February 2012 to February 2013 (TC1, $\mathrm{CP} 1$ and $\mathrm{CP} 2$ represents 24 measurements; ZD1 represents 6 measurements).

vydatnosti byly pozorovány na přelomu února a března, minimální pak v prosinci.

Elektrická vodivost skapů CP1, CP2 a ZD1 se pohybuje mezi 550 až $630 \mu \mathrm{S} / \mathrm{cm}$, zatímco u skapu TC1 je v rozmezí 275-350 $\mu \mathrm{S} / \mathrm{cm}$ (obr. 2b). Index nasycení kalcitem $\left(\mathrm{SI}_{\text {kalcit }}\right)$ se pro skapy $\mathrm{CP} 1, \mathrm{CP} 2$ a ZD1 pohybuje $\mathrm{v}$ rozmezí $0,8-1,2$, pro skap TC1 variuje blízko rovnováhy $(\mathrm{SI}=-0,1$ až 0,3$)$.

Poměr hořčík/vápník pro skapy CP1, CP2 a ZD1 se pohybuje v rozpětí 15-20. Pouze v př́padě skapu TC1 dosahuje téměř třikrát vyšších hodnot. Přitom obsah hořčíku je ve všech skapech velmi stálý ( $\mathrm{Mg} \sim 1,5 \mathrm{mg} / \mathrm{l})$.

\section{Diskuze}

Variabilita vydatnosti skapů CP2 a TC1 nižší než 50 \% indikuje celoročně poměrně stálé skapy s malými výkyvy. Tyto skapy odpovídají stabilním zdrojům vody v nadložní části krasu (visuté kolektory v epikrasu). Naopak vyšší variabilita vydatnosti skapů CP1 a ZD1 naznačuje sezónní povahu skapů s rychlým průtokem a menšími kolektory. Systematický pokles vydatnosti naznačuje, že primární zdroje vody $\mathrm{v}$ nadloží jeskynních prostor se v průběhu roku zvolna vyprazdňují a doplňují se pravděpodobně v obdobích tání sněhu. Občasné nárůsty vydatnosti po srážkách $\mathrm{v}$ průběhu roku mohou být způsobeny pístovým tokem, kdy infiltrující voda vytláčí starší vodu zachycenou v puklinách.

Z hlediska geochemických vlastností můžeme skapové vody v Punkevních jeskyních rozdělit do dvou skupin. První skupinu tvoří „běžné skapy“ CP1, CP2 a ZD1 - jejich mineralizace je velmi stálá, jak dokládá konduktivita (viz obr. 2b). U skapů CP1 a CP2 je patrná velká podobnost geochemických vlastností vod, ačkoli se hydrologicky velmi liší.

Druhou skupinu představuje skap TC1. Ten vykazuje anomální vlastnosti - nižší a variabilní konduktivita indikuje nižší celkovou mineralizaci ve srovnání se zbylými skapy, skap je blízko rovnováhy s kalcitem a poměr $\mathrm{Mg} / \mathrm{Ca}$ je zvýšený.

Relativně stabilní a vysoký průtok skapu TC1 ukazuje na objemný kolektor a delší časy zadržení. To vylučuje př́mý kontakt s povrchem, rychlý průtok vody krasovým prostředím a naředění málo mineralizovanou srážkovou vodou - mixování po srážkových událostech by způsobovalo velkou variabilitu vydatnosti. Proti mísení vod svědčí poměr $\mathrm{Mg} / \mathrm{Ca}$ - zatímco obsah hořčíku je obdobný jako v ostatních skapových vodách, obsah vápníku je výrazně nižší a určuje hodnotu poměru.

Anomální hodnoty indexu nasycení (tj. koncentrace karbonátů a vápníku) jsou nejpravděpodobněji způsobeny 
předchozím srážením kalcitu ve vyšších patrech jeskyní. Tento předpoklad potvrzují i dř́vější speleologické práce: komín nad skapem je přes dvacet metrů dlouhá, ukloněná prostora s jeskynní výzdobou (Glozar 1984), což dokladuje srážení kalcitu.

Vzhledem $\mathrm{k}$ několika zaznamenaným případům, kdy byl index nasycení ke kalcitu menší než 0 (viz obr. 2c), se na výsledném složení anomální vody pravděpodobně podílí vedle předchozího srážení kalcitu ještě další procesy. Index nasycení by mohl být záporný např́klad v situaci, (1) kdy se voda předběžně srážející kalcit opět dostane do prostoru $\mathrm{s}$ vyšším $\mathrm{P}_{\mathrm{CO}_{2}}$, rozpouští jej a stává se nenasycenou ke kalcitu. Dalším procesem (2) je mísení dvou různých vod původně $\mathrm{v}$ rovnováze $\mathrm{s}$ kalcitem.

\section{Závěr}

Na základě hydrogeochemické studie skapových vod v Punkevních jeskyních (Moravský kras) byl identifikován skap s anomálními vlastnostmi: nízkou mineralizací, stavem blízko rovnováhy s kalcitem, vysokým poměrem $\mathrm{Mg} / \mathrm{Ca}$ a relativně velkou a stálou vydatností. Analýzy dat naznačují, že se z vody tohoto skapu předběžně srážel kalcit ve volných prostorách v nadloží jeskyně. Existenci takovéto prostory nad skapem TC1 potvrzují speleologické výzkumy. Samotné předchozí srážení nicméně nevysvětluje všechny hydrochemické vlastnosti (např. SI < 0), takže na konečném stavu vody zřejmě participují další procesy, např́klad mixování různých typů vod. Přestože je anomální skap nenasycený ke kalcitu pouze ojediněle, nedovoluje spolehlivě zamítnout hypotézu chemické koroze speleotém skapovými vodami.

Zbývající studované „standardni“" skapy vykazují s výjimkou hydrologie velmi stejnorodé hydrogeochemické vlastnosti: zvýšenou mineralizaci, nižší poměr $\mathrm{Mg} / \mathrm{Ca}$ a značné přesycení kalcitem.

\section{Poděkování}

Výzkum byl institucionálně podpořen společností GEOtest, a. s., a Masarykovou universitou. Autoři dále děkují Jiřimu Hebelkovi ze Správy jeskyní Moravského krasu a RNDr. Antonínu Tůmovi ze Správy CHKO Moravskýkras za podporu při monitoringu. Díky patři také recenzentovi Mgr. Tomáši Kuchovskému, Ph.D. za podnètné pripomínky.

Literatura

Appelo, C. A. J. - Parkhurst, D. L. (1999): User's guide to PHREEQC (Version 2) - a computer program for speciation, batch-reaction, one-dimensional transport, and inverse geochemical calculations - Water-Resources Investigations Report, 99-4259.

Balák, I. (1984): Mineralogicko-petrografický a drobně tektonický výzkum Punkevních jeskyní. - MS, diplomová práce PřF UJEP Brno.

Faimon, J. - Zimák, J. - Zajíček, P. - Schwarzová, M. - Štelcl, J. (2004): The study of recent destructive processes in the Moravian Karts caves (Czech republic). - Geographica, (Acta Universitatis Palackianae Olomucensis, Facultas Rerum Naturalium), $38,1,9-13$.

Fairchild, I. J. - Borsato, A. - Tooth, A. F - Frisia, S. - Hawkesworth, C. J. - Huang, Y. - McDermott, F. \& Spiro, B. (2000): Controls on trace elements (Sr-Mg) compositions of carbonate cave waters: implications for speleothem climatic records. - Chemical Geology, 166, 255-269.

Fairchild, I. J. - Treble, P. C. (2009): Trace elements in speleothems as recorders of environmental change. - Quaternary Science Reviews, 28, 449-468.

Glozar, P. (1984): Průzkum komínových prostor v suché části Punkevních jeskyní. - Československý kras, 35, 87-93.

Jacobson, R. L. - Langmuir, D. (1974): Dissolution constants of calcite and $\mathrm{CaHCO}_{3}+$ from 0 to $50{ }^{\circ} \mathrm{C}$. - Geochimica et Cosmochimica Acta, 38, 301-318.

Morse, J. W. - Arvidson, R. S. (2002): The dissolution kinetics of major sedimentary carbonate minerals. - Earth-Science Reviews, $58,51-84$.

Smart, P. L. - Friederich, H. (1982): The classification of autogenic percolation waters in karst aquifers: A study in G.B. Cave, Mendip hills, England. - Proceedings University of Bristol Spelaeological Society, 16, 2, 143-159.

Tooth, A. F. - Fairchild, I. J. (2003): Soil and karst aquifer hydrological controls on the geochemical evolution of speleothem-forming drip waters, Crag Cave, southwest Ireland. - Journal of Hydrology, 273, 51-68. 